\title{
Modeling Investment Decision Through Perceived Risk
}

\author{
Pallavi Mishra
}

\begin{abstract}
Investors constantly struggle to make decision based on reason while evaluating and inferring information gathered from a variety of sources for diverse investment options to reach at an optimal investment choice. They are also affected by different psychological dimensions that affect them and bias their decision. The present study intended to study the effect of few general dimensions on investment decision with the mediation effect of perceived risk by using survey data of stock market investors. The paper has employed Structural Equation Modeling and concludes that perceived risk has partial mediation effect between investment decision and determinants of investment decision.
\end{abstract}

Key Word: Investment Decision, Perceived Risk, Investors' Psychology, Stock Market, India

AMS subject classifications number: 91B28, 62D05, $62 \mathrm{H99}$

\section{INTRODUCTION}

Stock market experiences various emotions from sensitivity to ignorance and is analogous to human feelings. Apart from the different external or macroeconomic and internal or company related factors affecting the stock market, a very important role is assumed by psychology. Psychology not only assists in rapid market advancement but also sharp fall. Nonetheless, each investor undergoes a set of diverse feelings and is readily defenseless. The much talked about established theory in finance i.e the Efficient Market Hypothesis (EMH) supposes that individual investors are completely rational and wish to maximize their expected utility. Their actions are not dependent on psychology or emotions. While this theory enlightened market behaviors and received worldwide acceptance (This theory bagged Nobel Prize for Fama), EMH could not convince the economists in general and the scientists of behavioral finance in particular.

Behavioral finance being a sub discipline of finance probes and elucidates the various aspects of human psychology. It aims at studying the impact of this psychology on making investment decisions in the financial market by employing concepts from the areas of psychology, sociology as well as finance. This aids in clarifying unusual response of investors that Traditional Finance could not comprehend entirely. This discipline of finance apprises normal investors in the real world who are influenced by psychological and emotional factors. When the market gives a feel good vibration the investors tend to become overoptimistic and when it is in a bad state, they tend to see the gloomy side of the story and become markedly pessimistic.

Revised Manuscript Received on 14 August, 2019.

Pallavi Mishra, Lecturer, Faculty of Management Sciences, Siksha O Anusandhan Deemed to be University, Bhubaneswar, Odisha, India (Email mishrapalllavi@gmail.com)
Experts on behavioral finance opine that there are a wide range of psychological factors that have an influence on the way the investors behave. Few factors that have received immense acceptance include optimism, pessimism, overconfidence, psychology of risk and herd behavior. Overconfidence involve overestimation of one's knowledge, underestimation of risks associated with a given situation and exaggeration of their skill to be in command of events. Investors are more likely to misjudge their capability and the accuracy of predictions made by them. They place excessively lower confidence intervals about their projections and overweigh their own estimations, in comparison to others. Self-serving bias and illusory superiority have been found to be the two major reasons contributing to investors' confidence.

Optimism is described as the propensity or proclivity to identify an occurrence or act as more expected to result in a favorable result, regardless of the objective likelihood of that consequence essentially taking place. $\left({ }^{9}\right.$ Fabre Bruno, et al 2009). in view of the fact that optimism and overconfidence generally go hand in hand and are strongly interrelated hence an optimistic person will be predisposed to be overconfident and vice-versa. ${ }^{23}$ Taylor et al, 1988). Nevertheless for every optimist visualizing the half full glass, there is the pessimist who sees the glass as half empty. Such people fetch their personal distinctive risks and issues to planning. Negativity bias surrounds the pessimist who is in anticipation of an apparently unavoidable event, particularly one that is not advantageous. Investors weigh bad news more than good news. Many may see this as merely being rational, but this prejudice pushes one to pay no attention to any opportunity of incentive and simply view everything that can be mistaken. According to ${ }^{16}$ Ricciardi Victor (2008), risk perception is the manner in which people view or believe a prospective threat or peril would emerge to be. The notion of risk perception tries to enlighten the assessment of a hazardous condition basing on inherent and intricate personal knowledge, decision making, and getting hold of knowledge from the external milieu (e.g., diverse sources of media). As quoted by ${ }^{21}$ Sitkin et al (1995) risk perception as "an individual's assessment of how risky a situation is in terms of probabilistic estimates of the degree of situational uncertainty, how controllable that uncertainty is, and confidence in those estimates". Instinctively an investor can be assumed to herd if he makes an investment decision without being aware of other investors' choice However he will choose not to invest if he discovers others' decision of not doing so. On the other hand he herds when

Blue Eyes Intelligence Engineering

\& Sciences Publication

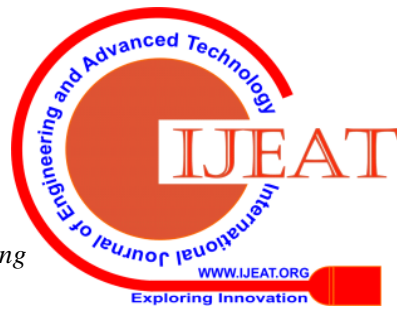


he recognizes that investors in the market are investing and alters his judgment of not making the investment to actually making it. ( ${ }^{6}$ Bikhchandani Sushil et al, 2000).

In this context the present study is proposed to estimate the effect of common dimensions of investment decision through perceived risk measurement.

\section{LITERATURE REVIEW}

Several economists, psychologists and sociologists have endeavored to appraise the actions of investors in the stock market from diverse standpoints. Economists emphasize a great deal on the rational and irrational facets of decisionmaking by investors so far as their behavior is concerned. Sociologists detail behavior of investors by stressing on his social background. Conversely, psychologists assess the same by laying more importance on individual traits $\left({ }^{18}\right.$ Shafi, 2014). Therefore, taken as a whole it may be concluded that numerous factors control peoples' decisions of making investments in the stock market. These factors can be categorized under two broad heads, namely internal and external. The most significant external items, as suggested by eminent researchers are cultural characteristics, economic state, political disruption, company related matters etc. Internal factors consist of psychological and personality traits whose appraisal has an extraordinary value in behavioral finance $\left({ }^{12}\right.$ Lodhi, 2014; ${ }^{5}$ Bennet et al., 2011; ${ }^{8}$ Doling Dowling et al., 2009; ${ }^{22}$ Subrahmanyam, 2007). Yet another categorization of these constructs can be common and uncommon components. The common ones contain psychological, demographic, social and financial features and uncommon factors comprise of inflation, promotion, multiplicity of goals, brand knowledge, economic prospects and stock market $\left({ }^{19}\right.$ Shafiee et al., 2016; ${ }^{7}$ Brown and Taylor, 2014; ${ }^{10}$ Gherzi et al., 2012; ${ }^{11}$ Kourtidis et al., 2011).

In yet another effort to bridge the gap between the disparity in relation to demographic profile and geographical location, ${ }^{4}$ Bakara Suzaida, et al (2016) probed the effect of psychological factor on investors' buying behaviour in the Malaysian stock market. Results evidenced that availability, overconfidence, bias and conservatism considerably impact decision of the investors. However their results showed no significant impact of herding behavior on the same. A similar study was conducted by ${ }^{24}$ Ton Hoang Thanh Hue et al (2014) in the Vietnam Stock Exchange. Findings suggested that investment decision in the long run was positively affected by optimism, risk psychology and pessimism and negatively by overconfidence and herd behavior.

${ }^{20}$ Sindhu K. P et al (2014) carried out a research and discovered a whole set of dimensions affecting investors' risk perception. Possibility for incurring loss, unpredictability of returns, diversification of portfolios, reliance on professional investment recommendation and information about the financial assets were explored to be the key drivers in the study. ${ }^{25}$ Trang Phung Thai Minh et al (2017) investigated the effect of perceived risk on performance of investment and purpose of individual investors. The study confirmed perceived risk's effect on both investment performance and intentions both directly and positively and intentions to invest indirectly. Investors were suggested to focus more on the investment risks associated with stocks tagged as "warn", "controlled", and "halted trading". More the risk is perceived, the higher will be their satisfaction from their investment decisions, current rate of return attained which will result in greater amount of investments subsequently. 'Abdeldayem Marwan Mohamed (2015) empirically tested the influence of investors' risk perception on portfolio management in Bahrain and consequently developed and tested a model of factors determining the variables under study. The outcome of the study disclosed that perceived portfolio risk was not only the effect of potential losses and gains that could be quantified but also qualitative manifestations. Level of confidence in the economy or the stock market, liquidity, worry \& anxiety mainly represented investors' perceived risk. ${ }^{3}$ Baghani Mohammad Reza et al (2016) studied how investors' decisions making was affected by risk perception and risk tolerance in the Tehran Stock Exchange. Results reported positive and direct and association between the explanatory variable and postulations on investors' decisions.

${ }^{17}$ Sachse et al (2012) recognized the pertinent characteristics of financial risk perception and compared with those employed by financial advisors with the purpose of checking whether individual investor characteristics were linked to perceived risk which could help to forecast the intent to invest. Two fundamental factors of perceived investment risk were discovered. One was concerned with losses and variability of the value invested over and above their associated behavioral outcomes like attention, worry, predictability and unpredictability. The other reflected issues of investment handling like liquidity, transparency etc. The study confirmed the role of qualitative aspects of the investment namely transparency, worry etc that determined perception of financial risks apart from quantitative aspects such as probability of loss and volatility of investment. ${ }^{15}$ Lubna Riaz (2015) scrutinized the function of different psychological constructs similar to asymmetric information, risk propensity and problem framing that influenced Pakistani investors' investment decision. Overall findings concluded that behavior of investors was dependent upon the quantum of existing information that was put forth before them and how ready they were to accept risk while making investment decisions; in consequence playing a major part in shaping investors' style of investment. ${ }^{27}$ Zeisberger Stefan et al (2014) studied the Dutch investors' risk perception with the intention of tracing out their key indicators. They also aimed to find out if investors were proficient in precisely estimating probability of loss in the stock market. The online survey of 757 respondents revealed that investors and prospective investors differentiated between gains and losses in a fairly strong manner giving second order importance to fluctuation and amount of returns. Hence, possibility of losing money was a vital gauge for how Dutch recognized risk which has a direct impact on tendency to invest specifically in the long run.

The risk perception of investment products in Switzerland was examined by ${ }^{26}$ Wang Mei et al (2008). The researchers 
reported high correlation between two scales namely knowledge-related and risk-related. Perceived knowledge was the central forecaster of perceived risk. There was a possibility that investors expected too much of risk in few investment avenues because of ignorance (knowledge deficient) and undervalued risk in few cases as they were more than confident about self-perceived knowledge. To fill the knowledge gap is important for effective risk communication. It was observed by them that whenever the respondents came across easier-to-understand products there they perceived the product to be less risky. Furthermore, they carried certain amount of home bias and underrated the risk of investment in the private real estate, which was on the other hand possibly caused by familiarity bias. Women were found to perceive higher risk in case of equity as an investment option and assumed other investment options such as gold, art, antique, etc as less risky than their male counterparts. Basically this must have been caused because of affect heuristic as men are fonder of investment in stocks and women in antique, art, and gold. ${ }^{13}$ Muthuswamy P.R.et al (2015) reported that investors in India have started gaining faith in the stock market and that there was enlarged female investors' participation. The possible reason for this was the increased consciousness and the accessibility of investible surplus. Investors' opinion on the conventional financial instruments to park their surplus funds was also seen shifting.

Taking into consideration of all such literature reviews, Figure 1 highlights the proposed model of the study.

Figure 1: Conceptual Model

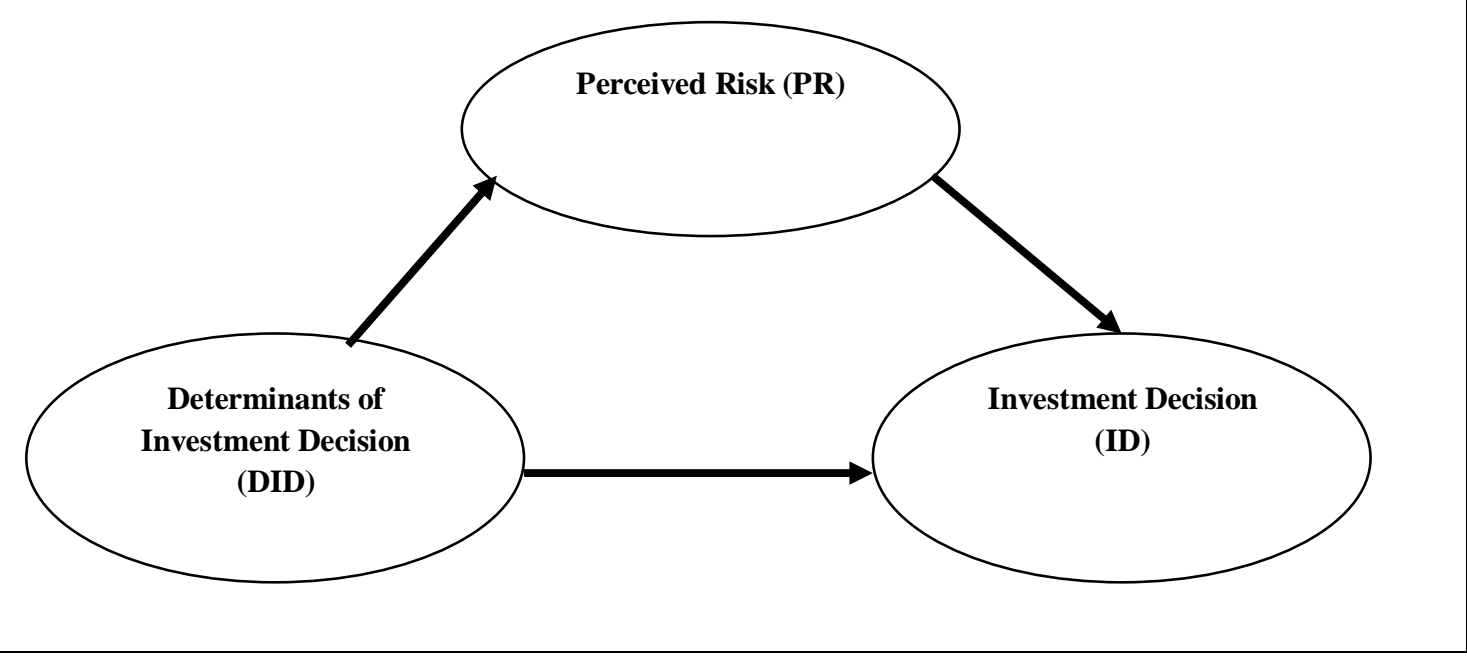

In the present study, the research hypotheses which would be empirically tested are as follows:

$\mathbf{H}_{\mathbf{1}}$ : Perceived risk of stock market investors plays a full mediating role in the relationship between determinants of investment decision and the actual decision itself.

\section{RESEARCH METHODS AND DESIGN}

The present study is of exploratory research design as it intends to explore the relationships among investors' psychological attributes for final investment decision making. To access the stock market investors in Eastern India, few brokers were contacted to finalise the respondents. Convenience sampling method was adopted to select the final sample respondents for primary data collection. The response scores in relation to investment decision produced a mean of 4.87 with a standard deviation of 0.395 from the pilot study. Maintaining a confidence level of $95 \%(Z$ - score $=1.96)$ and margin error of $4 \%$, the following sample size determination model produced result as below:

Necessary Sample Size $(\mathrm{n})=\left[(1.96)^{2} \mathrm{X}(0.395)^{2}\right] /(0.04)^{2}$ $=375$

In view of the non-responding attitude of stock market investors and their general invalid response in mind, a total of 450 investors were surveyed. Thereafter, 373 sample data were finally considered after editing the responses, which was nearer to the desired sample size of 375 as estimated. Data were collected through a structured survey instrument in which the research items were finalised referring the past developed measurement scales $\left({ }^{2}\right.$ Abroud, A , 2012, ${ }^{14}$ Nouri, B A et al 2017, ${ }^{24}$ Ton Hoang Thanh Hue et al., 2014). In oreder to finalise the measurement scales in survey instrument, the research items were tested for their reliability and validity scores through Cronbach's alpha and Confirmatory Factor Analysis (CFA). Finally, Structural Equation Model (SEM) was employed to test the formulated hypotheses of the study.

\section{RESULTS AND DISCUSSIONS}

The primary responses from the sample investors were coded and entered in SPSS worksheet for further data analysis. All the data were collecetd in seven point Likert scale form where 7 indicates 'strongly agree' and 1 indicates 'strongly disagree'. Table 1 shows the outcome of descriptive statistical analysis corresponding to the three research constructs of this study. Since the mean scores relating to the three dimensions are found to be above 4 , it indicates that all the responses are inclined towards strongly

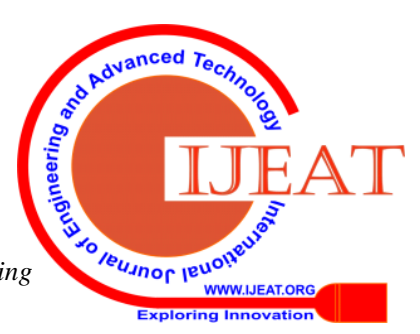


agree category in general. Standard Deviations for each of the dimensions are also below 50\% showing less variance in response.

\section{Table 1: Descriptive statistics of Research} Dimensions

\begin{tabular}{|c|c|c|c|}
\hline Variables & $\mathbf{N}$ & Mean & $\begin{array}{l}\text { Std. } \\
\text { Deviation }\end{array}$ \\
\hline $\begin{array}{l}\text { Determinants of } \\
\text { Investment } \\
\text { Decision (DID) }\end{array}$ & 373 & 4.63 & 0.41 \\
\hline $\begin{array}{l}\text { Perceived Risk } \\
\text { (PR) }\end{array}$ & 373 & 5.30 & 0.37 \\
\hline $\begin{array}{l}\text { Investment } \\
\text { Decision (ID) }\end{array}$ & 373 & 4.73 & 0.39 \\
\hline
\end{tabular}

Analysis of variance (ANOVA) was applied to know the impact of personal profile of investors on the dimensions of the study (Table 2). The results of ANOVA pointed out the existence of significant difference in the responses given by investors regarding determinants of investment decision with respect to gender. Similarly income and education level of investors were responsible for creating variance with respect to perceived risk.

Table 2: Results of one way ANOVA showing the impact of demographic features of investors on major study variables

\begin{tabular}{|c|c|c|c|c|}
\hline \multicolumn{3}{|c|}{$\begin{array}{l}\text { Causal link showing the Impact of Demographic Features on } \\
\text { Investors' Response }\end{array}$} & \multirow{2}{*}{$\begin{array}{l}\text { F-Ratio } \\
.228\end{array}$} & \multirow{2}{*}{$\begin{array}{l}\text { Sig. (p-level) } \\
.633\end{array}$} \\
\hline \multirow{3}{*}{ Gender } & $\begin{array}{l}\text { Determinants of } \\
\text { Decision }\end{array}$ & Investment & & \\
\hline & Perceived Risk & & 2.555 & .111 \\
\hline & Investment Decision & & 1.733 & .189 \\
\hline \multirow{3}{*}{ Age } & $\begin{array}{l}\text { Determinants of } \\
\text { Decision }\end{array}$ & Investment & $2.638 *$ & .034 \\
\hline & Perceived Risk & & 1.369 & .244 \\
\hline & Investment Decision & & 2.069 & .084 \\
\hline \multirow{3}{*}{ Occupation } & $\begin{array}{l}\text { Determinants of } \\
\text { Decision }\end{array}$ & Investment & 1.357 & .240 \\
\hline & Perceived Risk & & 1.652 & .146 \\
\hline & Investment Decision & & 1.492 & .192 \\
\hline \multirow{3}{*}{ Monthly Family Income } & $\begin{array}{l}\text { Determinants of } \\
\text { Decision }\end{array}$ & Investment & 2.587 & .053 \\
\hline & Perceived Risk & & $3.277 *$ & .021 \\
\hline & Investment Decision & & 2.090 & .101 \\
\hline \multirow{3}{*}{ Qualification } & $\begin{array}{l}\text { Determinants of } \\
\text { Decision }\end{array}$ & Investment & .559 & .732 \\
\hline & Perceived Risk & & $2.392 *$ & .037 \\
\hline & Investment Decision & & .780 & .565 \\
\hline \multirow{3}{*}{ Location } & $\begin{array}{l}\text { Determinants of } \\
\text { Decision }\end{array}$ & Investment & .534 & .587 \\
\hline & Perceived Risk & & 2.422 & .090 \\
\hline & Investment Decision & & .619 & .539 \\
\hline
\end{tabular}

*significant at $5 \%$ level

Path diagrams were drawn and analyzed for all data collected from stock market investors through Amos software package after determination of all the latent variables and their respective research items from literature review. Figure 2, is the final structural equation model of investors' response scores. 
Fig 2: Structural Equation Model showing the relationship among DID, PR and ID

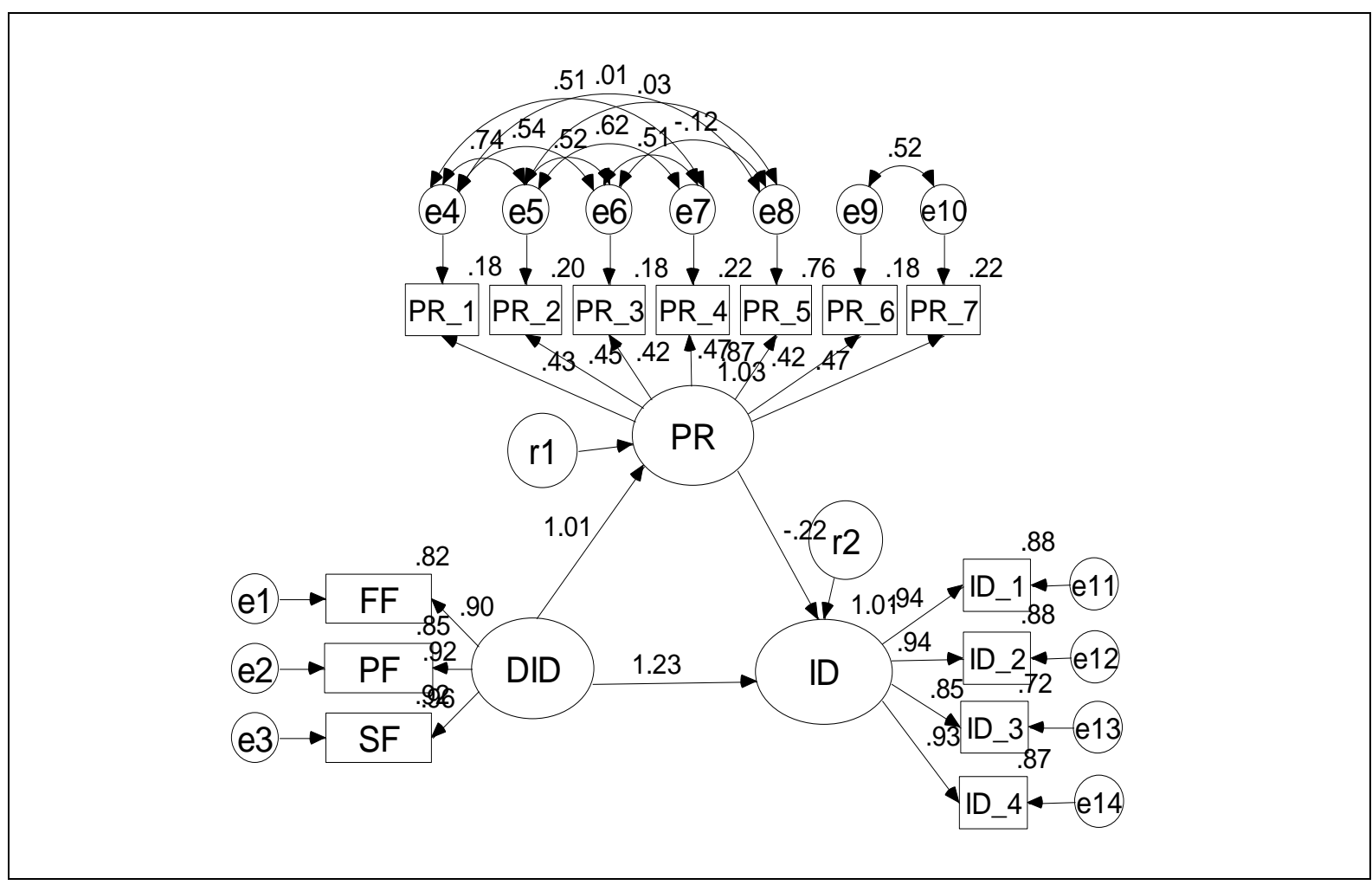

Table 3 represents few indices of goodness of fit of the model. As can be seen the fit indices were found to be satisfactory. Since the accepted range of fit indices is above 0.90 , all of the fit indices found for the data collected fulfill this criteria. Yet again the root mean square error of approximation (RMSEA) had a value of 0.071 , which is relatively low and as a result is fairly good. The cutoff value of error approximation of SEM is maximum upto 0.08 .

Table 3: Goodness of Fit Indices related to SEM of DID-PR-ID

\begin{tabular}{lc}
\hline Indices & Values \\
\hline Goodness of Fit Index (GFI) & 0.907 \\
Normed Fit Index (NFI) & 0.954 \\
Relative Fit Index (RFI) & 0.935 \\
Comparative Fit Index (CFI) & 0.965 \\
Root Mean Square Error of & 0.071 \\
Approximation (RMSEA) & \\
\hline
\end{tabular}

Table 4 depicts the unstandardized regression coefficient scores established after analysing two types of models, one without the mediating variable (PR), and the other with the intervention of PR.

Table 4: Regression weights related to different paths of SEM linking DID, PR, and ID

\begin{tabular}{lllll}
\hline $\begin{array}{l}\text { Paths of } \\
\text { relationship }\end{array}$ & Estimate & S.E. & C.R. & P \\
\hline $\begin{array}{l}\text { DID } \rightarrow \text { ID } \\
\text { DID } \rightarrow \text { PR }\end{array}$ & 0.862 & 0.023 & 37.478 & 0.000 \\
$\rightarrow$ ID & 1.17 & 0.449 & 2.605 & 0.009 \\
\hline
\end{tabular}

As can be seen from table 4, the influence of DID on ID in both of the model types, i.e with and without perceived risk intervention was statistically significant at 0.01 level.
However, there was an increase in the regression weight scores after the introduction of perceived risk in between DID and ID. This confirms the existence of partial mediation effect of PR supporting the formulated hypothesis partly.

\section{MANAGERIAL IMPLICATIONS}

To craft an investment decision successfully, the investor has to opt for the right stock among diverse choices at the right time. With this aim of selecting superior stock evaluation of different options and criteria specification for alternative minimization and ranking is required. The conditions or factors that shape investment decision may be classified as rational or logical dimension group and the irrational dimension group. The analytical constructs are elementary gauge to assess company, industry, country as well as technical indicators to estimate pattern of company prices. Attitude, behavior, and characteristics are a few to name under the irrational factors category. Decision making is a cognitive procedure of carrying out different selection, from an extensive series of investment avenues on the basis of information and resources we have in hand.

Behavioural finance talks of how people make investment decision and are affected by internal factors and bias. Risk appetite differs from one individual to another. We continually are confronted with situations that call for choice among actions based on different risk level. In majority of the cases, while dealing with risk, human beings rely on their experience, perception, impulse and impression. Yet, risk taking is not a lone feature but is an action affected by situational characteristics, the one taking 
the decision and the interface between situation and decision maker. Understanding risk taking, who assumes risks, at what point and the reason behind doing so is on the whole the center of focus when the purpose is to manipulate and alter investor behavior.

\section{REFERENCES}

1. Abdeldayem, M M. The Impact of Investors' Perception of Risk on Portfolio Management: Evidence from the Kingdom of Bahrain. Research Journal of Finance and Accounting. Vol 6 (No 12) (2015) 61-79.

2. Abroud, A. Factors Affecting Investors' Perceived Intention on Online Stock Trading Adoption in Iran. Thesis submitted to Multimedia University. Malaysia (2012)

3. Baghani, M R, Sedaghat, P. Effect of Risk Perception and Risk Tolerance on Investors' Decision Making in Tehran Stock Exchange. International Academic Journal of Accounting and Financial Management. Vol 3 (No 9) (2016) 45-53.

4. Bakara, S, Yi, A N C. The Impact of Psychological Factors on Investors' Decision Making in Malaysian Stock Market: A Case of Klang Valley and Pahang. Procedia Economics and Finance. (No 35) (2016) 319 328.

5. Bennet, E., Selvam, M., Indhumathi, G., Ramkumar, R. R., and Karpagam, V. Factors Influencing Retail Investors' Attitude towards Investing in Equity Stocks: A Study in Tamil Nadu. Journal of Modern Accounting and Auditing. Vol 7 (No 3) (2011) 316-32.

6. Bikhchandani, S, Sharma, S. Herd Behavior in Financial Markets: A Review. IMF Working Paper. (No. 00/48) (2000).

7. Brown, S., Taylor, K. Household Finances and the 'Big Five' Personality Traits. Journal of Economic Psychology. Vol 45 (2014) 197-212.

8. Dowling, Doling, N. A., Corney, T., Hoiles, L. Financial Management Practices and Money Attitudes as Determinants of Financial Problems and Dissatisfaction in Young Male Australian Workers. Vol 20 (No 2) (2009) 5-13

9. Fabre, B, Heude. A F. Optimism and Overconfidence Investors' Biases: A Methodological Note. Revue de l'associationfrançaise de finance. Vol 30 (No 1) (2009) 79-119.

10. Gherzi, S., Egan, D., Haisley, E., Ayton, P. Meerkats, Not Ostriches: Portfolio Monitoring, Individual's Differences and Investors' Trading Behavior: Mimeo, City University London.( 2012)

11. Kourtidis, D., Sevic, Z., Chatzoglou, P. Investors' Trading Activity: A Behavioral Perspective and Empirical Results. Journal of Socio-Economics. Vol 40 (No 5) (2011) 548-557.

12. Lodhi, S. Factors Influencing Individual Investor Behavior: An Empirical Study of City Karachi. Journal of Business and Management. Vol 16 (No 2) (2014) 6876.

13. Muthuswamy P.R, Devi R.Rathi. Investors Risk Perception and Investors Information Seeking Behaviour on Investment Decision. International Journal of Management Research \& Review. Vol 5 (No 2) (2015) 91-100.

14. Nouri, B A, Motamedi, S. Soltani, M. Empirical Analysis of the Financial Behaviour of Investors with Brand Approach (Case Study: Tehran Stock Exchange). Scientific Annals of Economics and Business, Vol 64 (No 1) (2017) $97-121$.

15. Riaz, L, Hunjra, A I. Relationship between Psychological Factors and Investment Decision Making: The Mediating
Role of Risk Perception. Pakistan Journal of Commerce and Social Sciences. Vol. 9 (No 3) (2015) 968-981.

16. Ricciardi, V. Handbook of Finance, Investment Management and Financial Management. Wiley, 2008.

17. Sachse, K, Helmut, J, Julia, M. B. Investment risk-The perspective of individual investors. Journal of Economic Psychology. Vol 33 (No 3) (2012) 437-447.

18. Shafi, M. Determinants Influencing Individual Investor Behavior in Stock Market: A Cross Country Research Survey. Arabian Journal of Business and Management Review. Vol 2 (No 1) (2014) 60-71.

19. Shafiee, S. S., Moradi, M., Rahmani, H. An Empirical Study of Factors Affecting Investors' Decisions in the Iranian Stock Market: A combined DEMATEL-ANP approach. Aestimatio, The IEB International. The Journal of Finance. Vol 9 (2016) 112-149.

20. Sindhu K. P, Kumar S. Rajitha. Influence of Risk Perception of Investors on Investment Decisions: An Empirical Analysis. Journal of Finance and Bank Management. Vol 2, (No. 2) (2014) 15-25.

21. Sitkin, S. B., Weingart, L. R. Determinants of risky decision-making behavior: A test of the mediating role of risk perceptions and propensity. Academy of Management Journal. Vol 38 (No 6) (1995)1573-1592.

22. Subrahmanyam, A., Behavioral Finance: A Review and Synthesis. European Financial Management. Vol 14 (No 1) (2007) 12-29.

23. Taylor, S.E., Brown, J.D. Illusion and well-being: a social psychological perspective on mental health Psychological Bulletin. Vol 103 (No 2) (1988) 193-210.

24. Ton, H T H, Dao, T K. The Effects of Psychology on Individual Investors' Behaviors:Evidence from the Vietnam Stock Exchange. Journal of Management and Sustainability. Vol 4 (No 3) (2014) 125-134.

25. Trang, Phung Thai Minh, Tho, Nguyen Huu. Perceived Risk, Investment Performance and Intentions in Emerging Stock Markets. International Journal of Economics and Financial Issues. Vol 7 (No 1) (2017) 269-278.

26. Wang, M, Keller, C, Siegrist, M. The Less You Know, the More You Are Afraid of-A Survey on Risk Perceptions of Investment Products. Journal of Behavioral Finance. Vol 12 (No 1) (2011) 9-19.

27. Zeisberger, S., Langer, T., Weber, M. Do changes in reporting frequency really influence investors' risk taking behavior? Myopic loss aversion revisited. (2014). https://ssrn.com/abstract $=1786360$ 